\title{
THE VULNERABILITY OF THE YOUNG ADULT CONSUMER TO FOOD CONSUMPTION
}

\author{
A VULNERABILIDADE DO CONSUMIDOR JOVEM ADULTO AO CONSUMO DE ALIMENTOS
}

Recebido em 23.04.2021 Aprovado em 22.06.2021

Avaliado pelo sistema double blind revien

DOI: https://doi.org/10.12712/rpca.v15i1.49764

\author{
Bruno Medeiros Ássimos \\ bruno.assimos@gmail.com \\ Programa de Pós-graduação em Administração - Pontifícia Universidade Católica de Minas Gerais - Minas \\ Gerais - Brasil \\ http://orcid.org/0000-0003-1206-6376
}

Marcelo de Rezende Pinto

marcrez@hotmail.com

Programa de Pós-graduação em Administração - Pontifícia Universidade Católica de Minas Gerais - Minas

Gerais - Brasil

https://orcid.org/0000-0002-3251-2460

\author{
Adriana Ventola Marra \\ aventola@ufv.br \\ Universidade Federal de Viçosa - Minas Gerais - Brasil \\ https://orcid.org/0000-0003-3405-0308
}

\begin{abstract}
Vulnerability is a central theme for studies involving discussions between the relationship between marketing and society. Vulnerability can occur in different fields, including food. In this context, one of the main dietary problems in Brazil refers to excess weight, which affects about $25.4 \%$ of adolescents and $53.8 \%$ of adults. Thus, this paper sought to measure the vulnerability of young adults between 18 and 24 years old using the vulnerability scale proposed by Chi et al. (2017), relating it to the scale of nutritional interest of Balasubramanian and Cole (2002). It was possible to identify more evidence of significance between product knowledge and nutritional interest, reinforcing the importance of information for the satisfactory evaluation of consumers and the reduction of their vulnerability.
\end{abstract}

Keywords: Consumer Vulnerability. Nutritional Interest. Food Consumption. Young Adult.

\section{Resumo}

A vulnerabilidade é uma temática central para os estudos envolvendo as discussões entre a relação entre marketing e sociedade. A vulnerabilidade pode se dar em diferentes campos, incluindo a alimentação. Nesse contexto, um dos principais problemas alimentares do Brasil refere-se ao excesso de peso que atinge cerca de $25,4 \%$ dos adolescentes e $53,8 \%$ dos adultos. Assim, este trabalho buscou mensurar a vulnerabilidade de adultos jovens entre 18 e 24 anos por meio da escala de vulnerabilidade proposta por Chi et al. (2017), relacionando-o à escala de interesse nutricional de Balasubramanian and Cole (2002). Foi possível identificar maiores evidências de significância entre conhecimento do produto e interesse nutricional, reforçando a importância da informação para a avaliação satisfatória dos consumidores para a redução da sua vulnerabilidade.

Palavras-chave: Vulnerabilidade do Consumidor. Interesse Nutricional. Consumo de Alimentos. Jovens Adultos. 


\section{Introduction}

Much of the discussion on consumer vulnerability is based on groups of disadvantaged people, as is common to see in the literature of Transformative Consumer Research, for example. That is, demographic variables such as age, education and income have a relevant weight in these discussions (Almeida et al., 2017; Garrett \& Toumanoff, 2010; Jae \& Viswanathan, 2012). In addition to them, the importance of the context unveiled as an influential element in more recent research for the understanding of consumer vulnerability, not only contexts related to behavior, but also to marketing practices (Ringold, 2005). In these cases, vulnerability is the result of consumers' internal and external social interactions (Baker et al., 2005; Commuri \& Ekici, 2008).

But for Chi et al. (2017), contexts are also not enough. For the authors, the provision of useful information to public policy managers needs to go beyond demographics and contexts, and must assume all possibilities through a precise, practical and universal approach. For this, and based on the model of Baker et al. (2005), the authors propose a measurement instrument that takes into account demographics and individual states based on behavioral trends affected by certain stimuli (which would be all marketing tools) in market contexts, also providing information about the decrease in well-being as a possible consequence, which results in the lack of knowledge and impotence on the part of the consumer. Thus, the authors consider that consumer vulnerability is an individual characteristic that results in trends for decision-making that can harm well-being when influenced by external factors in a consumption situation. In addition, they consider that everyone can experience vulnerability as a result of internal and external influences, varying only in the degree of vulnerability experienced. Chi et al. (2017) differentiate between vulnerable and disadvantaged consumers, the latter being the most commonly found in groups pointed out by theoretical debates carried out by the Transformative Consumer Research (ACR, 2019). Finally, the authors explore the vulnerability of consumers, in addition to individual factors, such as social pressure.

The work developed by Chi et al. (2017), for assuming a universal application, it can be used as an instrument for measuring the vulnerability of young Brazilian consumers in the food market. In Brazil, citizens who consume more ultra-processed foods are $37 \%$ more likely to be obese than individuals who consume less ultra-processed foods (Canella et al., 2018; Silva et al., 2018). This percentage becomes even more worrying when evaluating the composition of the average diet of Brazilians, $20.4 \%$ composed of ultra-processed foods, which are those directly associated with the higher consumption of free sugar and total sugar, trans and saturated fat (Louzada, 2018). As a consequence, one of the major food problems in Brazil refers to overweight, which in a survey conducted by IBGE (2010), affects about $25.4 \%$ of adolescents and $53.8 \%$ of adults.

Thus, any food analysis must take into account the characteristics of a market system, including production and marketing, given that such an organization has the capacity to promote some degree of social and environmental protection, as provided for in national legislation; or, on the contrary, the hegemonic reproduction of the interests of one voice strongly unbalances power relations and generates even more inequalities and threats, which increases the vulnerability of the consumer (BRASIL, 2014). Under the sphere of the Consumer Protection Code (CPC) (1990), as established by the Federal Constitution (CF) in its article 5, item XXXII, the state has the function of promoting consumer protection, that is, it is a constitutional state commitment foreseen in the observation of the economic order (CF, article 170, caput and item V). The CPC regulates an unequal relationship in consumer relations, unlike the Civil Code, which deals with interactions between equals. Thus, vulnerability is an assumption of the condition of a consumer, as a result of the market structure.

Measure the vulnerability of young Brazilian adults between 18 and 24 years old using the scale proposed by Chi et al. (2017) (composed of seven dimensions of vulnerability: product knowledge, 
promotion/advertising, social pressure, refund policies, marketing and emotional pressure, distinguishing ability, purchasing ability) and relate it to the Balasubramanian and Cole scale of nutritional interest (2002) demonstrates the concern of this work in unveiling the vulnerability of young Brazilians in a market increasingly permeated by food options. In order to reveal part of this scenario, this research obtained 849 responses collected during three weeks, and its collection occurred between the end of November and the beginning of December 2019. Of these, 564 responses were considered valid according to the age criterion adopted.

For the Organization for Economic Cooperation and Development (OECD) (2019), obesity is a pandemic in which the causes of its increase revolve around inadequate diets and lack of physical activity. As a result, they overload health systems and have negative consequences on school performance. The OECD (2019) admits that a reduction in calorie intake could have an impact on the reduction of cardiovascular diseases, chronic respiratory diseases, diabetes mellitus and neoplasias, on health costs, an increase in the productive workforce and a positive impact on GDP of a country by about $0.5 \%$, all because the obesity pandemic causes $60 \%$ of new cases of diabetes, $18 \%$ of cardiovascular diseases, $11 \%$ of dementia, $8 \%$ of cancers, 3 million premature deaths and reduction up to 4 years in life expectancy, which in itself justifies analyzing the important relationship between consumer vulnerability and nutritional reading.

Based on such theoretical premises, it becomes relevant to study which variables most influence the construction of this consumer's vulnerability, since his present choices will shape a lifestyle that will have a future impact on his health over the years. It is worth considering that consumer vulnerability in its various dimensions, including that caused by food, is a central theme for studies involving the relationship between marketing and society. In the same sense, a better understanding of the elements, antecedents and consequences of vulnerability can be revealing for the elaboration and execution of public policies in countries like Brazil.

To this end, the theoretical framework revisits some debates on consumer vulnerability from a legal and market point of view, followed by a brief discussion about the main consumer analysis tool in the food market, the information contained on the labels.

\section{Theoretical framework}

\section{Consumer vulnerability}

The concept of consumer vulnerability is interdisciplinary, studied mainly by the correct areas of management, consumption and law. The CPC measured part of the presumption of vulnerability of the consumer, recognizing the existence of an unequal power relationship between the parties. In its article 2 , the CDC provides the following definition of consumer: "it is any natural or legal person, who purchases or uses a product or service as a final recipient" (law No. 8,078, of September 11, 1990). Although its interpretation goes beyond the individual consumer, this is what this work will focus on. Therefore, for the law, the vulnerability comprises the condition of inferiority of the consumer vis-à-vis the supplier, which would justify the implementation of protective legal rules, since for the legislation, the former would be more susceptible to suffer damage against the productive domain of the latter. In general, the legal duty is manifested under two weights, for the supplier as the duty of care, when putting into circulation suitable products or services that do not cause legally unjustified damage, and to the consumer, who has the power to act if this duty is not fulfilled (Nunes, 2013; Grinover, 2011; Dworkin, 2010; Moraes, 1999). In this sense, it is relevant to conceptualize product and service from the same point of view. According to paragraph 1 of article 3 of the CPC, "product is any asset, movable or immovable, material or immaterial.", paragraph 2 of article 3 of the CPC brings the definition of service: "is any activity provided in the consumer market, for remuneration, including those of a banking nature, financial, credit and insurance, except those arising from labor relations" 
Thus, in the legal sphere, "vulnerability is a permanent or provisional situation, individual or collective, which weakens, weakens the subject of rights, unbalancing the consumption relationship. Vulnerability is a characteristic, a state of the weaker subject, a sign of the need for protection" (Marques, 2014, p. 3). Some of the actions aimed at mitigating consumer vulnerability can be observed in law number 10,674, of 16 May 2003, which forced the food industry to inscribe on the label the expression "contains gluten", helping those with celiac disease. In 2016, the Federal Supreme Court (FSC) decided that "commerciallybased advertising campaigns that use or manipulate the children's play universe" involve abusive advertising (FSC, 2017).

However, the big question is that "voluntary waiver is allowed and without vices of will of certain projections regarding the exercise of a right, since limitation and self-limitation of rights are possible" (Pasqualotto \& Soares, 2017), thus, it is possible that the consumer purchased a product rich in sugar and fat, known to be unhealthy, without it being possible to say that the supplier has failed to observe the duty of care, meeting the product to the requirements of quality, production, correct and complete information, and distribution and consumption conditions, according to broad or specific legislation (Novais, 2006).

From the perspective of marketing, consumer vulnerability has been studied more recently with greater diligence through the lens of macromarketing and through transformative consumer research (Silva et al., 2016). For the latter, some groups deserve more attention because they are considered more vulnerable, such as the elderly, children, young people, the poor, illiterate and disabled (ACR, 2019). One of the most used concepts in marketing management to understand vulnerability comes from Baker et al. (2005), revealing a state of impotence in the face of imbalances in market relations, revealing a certain parity between legal and market discussions. For the authors, this state would be the result of interactions arising from individual characteristics, being biophysical and psychosocial; the individual states of sadness, motherhood, motivation, transition and others; external conditions of discrimination, repression and stigma, distribution of resources, physical elements, logistical elements, among other conditions; all of them highlighting the context of experiencing vulnerability, especially those controlled by marketing, such as advertising, the internet, prices, products, and other forms of communication. Still for the authors, the context experienced would cause coping strategies and the emergence of regulatory market policies that would facilitate or prevent the control of this environment.

Other variables can restrict the consumer, such as low cognitive capacity, information asymmetry and reduced mobility (Cooper-Martin, 1997). For example, information asymmetry affects the market, impacting society, as any consumer is subject to experiencing contexts where the uneven distribution of information compromises the ability to choose (Mascarenhas et al., 2008), which can make people suffer two main consequences, the inability to carry out a satisfactory assessment between cost and benefit and the lack of adequate guidance by the supplier (Afzal et al., 2009). Asymmetry can provoke mental rules that lead to a quick decision based on the experience, common sense or influence of advertising (Solomon, 2010), the latter being able to further increase the information asymmetry through persuasion, irrelevance or repetition of campaigns, in addition to misrepresentation of information. The greater the asymmetry, the greater the chances of consumer misunderstandings (Mascarenhas et al., 2008). Understanding information dysfunctions would help to increase social justice (Ássimos et al., 2017).

In the case of the food industry, one of the main sources of information is labels, which can serve several purposes, such as presenting information about nutrients. This consumer assessment instrument is also governed by legislation (Abicht et al., 2017), as discussed below.

\section{Label and nutritional information}


Item III of the CPC has as a basic right of the consumer clear information about services and products, specifying perfectly their characteristics, quantity, quality, composition, the taxes that affect them, as well as the risks inherent to them and the price. Thus, the National Consumer Relations Policy brings with it transparency and harmony in the relationship between the parties, consumer and supplier (Alves \& Varella, 2016).

With regard to food products, one of the essential sources of information concerns the label, as it is the first link between the parties. Decree-Law No. 986 of 1969, which establishes basic food standards, provides in Article 2, item XII, the definition of a label as an identification through lithography, printing, painting, fire or pressure engraving, on any type of packaging of food. This definition is taken up by Article 31 of the CDC, which states that "the presentation of the products must ensure the correct, clear and precise information, ostentatious and in the Portuguese language", in addition to constituting an advertising channel (Alves \& Varella, 2016).

According to the resolution of the collegiate board number 26, of July 2, 2015, of the National Health Surveillance Agency (NHSA), it is mandatory to declare the presence of wheat, rye, barley, oats and their hybridized strains; crustaceans; eggs; fish; peanut; soy; milks from all species of mammalian animals; almond; hazelnuts; cashew nut; Brazil nut; macadamias; pecans; pistachios; pine nut; chestnuts and natural latex. RDC number 360, of December 23, 2003, states that nutrition labeling "is all description intended to inform the consumer about the nutritional properties of a food" and states that nutrition labeling includes the declaration of energy and nutrient value, and the declaration of nutritional properties contained in foods. The said RDC advocates that the amount of energy value and the following nutrients must be declared: energy value, carbohydrates, proteins, total fats, saturated fats, trans fats and sodium. In addition to providing instructions on how to present daily reference values, daily nutrient intake, ways to perform calculations, visual presentation, units of measurement, portions and format of the nutritional table.

\section{Methodology}

The methodology outlined that resulted in the presentation of statistical data analysis was built in four stages. The first covered the descriptive analysis of demographic data (gender, age group, total family income, education, BMI classification, height, weight and BMI). For qualitative demographic variables, the absolute and relative frequency of each category was indicated, and for quantitative variables, measures of central tendency (mean), variability (standard deviation, minimum and maximum) and distribution histograms were evaluated. As for the variable BMI, this was calculated for each respondent considering the relationship between their weight and their height, with BMI $=$ Weight $/$ Height $^{2}$ (equation 1). The results were classified into six categories (table 1), according to criteria established by the World Health Organization (2019).

Table 1 - Classification of Body Mass Index

\begin{tabular}{l|l}
\hline BMI & Classification \\
\hline Under 18.5 & Under weight \\
$18.6-24.9$ & Normal weight \\
$25.0-29.9$ & Over weight/Pre-obesity \\
$30.0-34.9$ & Obesity Level \\
$35.0-39.9$ & Obesity Level II \\
Over 40.00 & Obesity Level III \\
\hline
\end{tabular}

Source: World Health Organization, 2019. 
In the second stage, the reliability of the instrument used in data collection was examined. According to Hair et al. (2005, p.111), reliability "is an assessment of the degree of consistency between multiple responses of a variable", and in this work, it was verified from a diagnostic measure called Cronbach's alpha that "ranges from 0 to 1 , the values of 0.60 and 0.70 being considered the lower limit of acceptability" (Hair et al., 2005, p. 90).

The third stage focused on performing the descriptive analysis of nutritional interest and the vulnerability dimensions from the histograms of the distributions and the same measures of central tendency and variability used to evaluate the demographic data. To calculate the score of respondents in each dimension, the simple average of the respective indicators was used. A new variable named (global) vulnerability was also calculated from the simple average of the responses presented by the respondents in the 6 dimensions of vulnerability considered.

The fourth section aimed to analyze the relationship between nutritional interest (dependent variable) and the dimensions of vulnerability, sex, education, income, BMI and BMI classification (independent variables). For this purpose, 3 techniques were used: correlation analysis, dispersion graph and regression analysis.

The correlation analysis aimed to identify the existence of a linear relationship between the dependent and independent variables, that is, to verify whether the relationship between them could be described using a first degree function. The correlation coefficient varies from negative to positive. The sign indicates the direction of the relationship (positively or negatively associated) and the coefficient suggests the strength of the relationship between the variables (Hair Jr. et al., 2005). For Cohen (1988), coefficients with values between $\mid 0.10$ and $0.29 \mid$ they can be considered small; scores between $\mid 0.30$ to $0.49 \mid$ can be taken as medium; and values between $\mid 0.50$ and $1 \mid$ can be considered great.

Linear regression, in turn, aimed to estimate or predict the "average value (for the population) of the dependent variable based on the known, or fixed, values of the explanatory variable" (Gujarati; Porter, 2011, p. 59). For regressions with only 1 predictor, the regression line has the following form: $\mathrm{Yi}=\beta 1+$ $\beta 2 \mathrm{Xi}+u_{\mathrm{i}}$ (equation 2), for 2 predictors: $\mathrm{Yi}=\beta 1+\beta 2 \mathrm{Xi}+\beta 3 \mathrm{Xi}+\iota_{\mathrm{i}}$ (equation 3 ), where: $\beta 1=$ intercept; $\beta 2=$ slope linked to the first predictor; $\beta 3=$ slope linked to the second predictor; $u_{\mathrm{i}}=$ error term. It represents "all omitted or neglected variables that can affect $Y$, but were not (or could not be) included in the regression model" (Gujarati; Porter, 2011, p. 64). The assumptions linked to the regression analysis, as indicated de Gujarati and Porter (2011) are: linearity between the dependent and the independent variable; lack of multicollinearity between the independent variables; homoscedasticity of the error term, normality of the error term; no self-correlation between the terms of error.

The quality of the adjustment performed by the regression analysis was assessed by the coefficient of determination $\mathrm{R}^{2}$ and adjusted $\mathrm{R}^{2}$. Both refer to a measurement that varies from 0 to 1 , so that values closer to 1 indicate a better fit since they represent greater proximity between the estimated values of $\mathrm{Y}$ and its value observed in the sample. R2 should be considered when there is only 1 predictor in the model and R2 adjusted when there are 2 or more. The adjusted R2 coefficient is "a corrective measure to compensate for the effect of adding regressors that increase the value of R2" (Gujarati; Porter, 2011. p. 492).

The existence of influential values was assessed using the standardized waste dispersion graph versus predicted values and Cook's distance coefficients. The latter refer to a "summary measure of the influence of a single case (observation) based on the total changes in all other residues when the case is eliminated from the estimation process (Hair et al., 2005, p. 188). The homogeneous arrangement of points on the Cook's distance graph and Cook distance values less than 1 indicate the absence of influential values (Hair et al., 2005). 
Finally, the data analysis was processed using the Minitab and R statistical software, and its results can be seen in the next section.

\section{Analysis of the results}

\section{Descriptive analysis of demographic variables}

This research includes a sample of 564 respondents, formed mostly by women (51.6\%), by individuals aged between 18 and 24 years $(93.6 \%)$, by people with total family income between 4 and 8 minimum salary (MS) (28.4\%), by those who have completed high school/incomplete higher education (88.3\%) and those who have normal weight $(67.3 \%)$, according to criteria established by the World Health Organization (2019). These results are found in table 2.

Table 2 - Distribution of respondents by qualitative demographic data - Absolute and relative frequency

\begin{tabular}{|c|c|c|c|}
\hline \multirow{2}{*}{\multicolumn{2}{|c|}{ Demographic Variable }} & \multicolumn{2}{|c|}{ Frequency } \\
\hline & & \multirow{2}{*}{$\frac{\text { Absolute }}{291}$} & \multirow{2}{*}{\begin{tabular}{|l} 
Relative (\%) \\
51.6
\end{tabular}} \\
\hline \multirow{2}{*}{ Gender } & Female & & \\
\hline & Male & 273 & 48.4 \\
\hline \multirow{2}{*}{ Age group } & Up to 17 years old & 36 & 6.4 \\
\hline & Between 18 and 24 years old & 528 & 93.6 \\
\hline \multirow{6}{*}{ Total family income } & Under or equal to1 MS $(\mathrm{R} \$ 998,00)$ & 30 & 5.3 \\
\hline & $\begin{array}{l}\text { Between } 1 \text { and } 2 \text { MS ( } \mathrm{R} \$ 998,01 \text { to } \mathrm{R} \$ \\
1.996,00)\end{array}$ & 94 & 16.7 \\
\hline & $\begin{array}{l}\text { Between } 2 \text { and } 4 \text { MS ( } R \$ 1.996,01 \text { to } R \$ \\
3.992,00)\end{array}$ & 159 & 28.2 \\
\hline & $\begin{array}{l}\text { Between } 4 \text { and } 8 \text { MS }(\mathrm{R} \$ 3.992,01 \text { to } \mathrm{R} \$ \\
7.984,00)\end{array}$ & 160 & 28.4 \\
\hline & $\begin{array}{l}\text { Between } 8 \text { and } 18 \text { MS (R\$7.984,01 a } \mathrm{R} \$ \\
17.964,00)\end{array}$ & 81 & 14.4 \\
\hline & Over 18MS (Over $\mathrm{R} \$ 17.964,00)$ & 40 & 7.1 \\
\hline \multirow{4}{*}{ Education } & $\begin{array}{l}\text { High School Completed / Middle school } \\
\text { incomplete }\end{array}$ & 32 & 5.7 \\
\hline & $\begin{array}{l}\text { Middle school complete / College } \\
\text { incomplete }\end{array}$ & 498 & 88.3 \\
\hline & College Complete & 25 & 4.4 \\
\hline & $\begin{array}{l}\text { Incomplete or complete posgraduate } \\
\text { studies }\end{array}$ & 9 & 1.6 \\
\hline \multirow{5}{*}{$\begin{array}{l}\text { Classification of body } \\
\text { mass index (BMI) }\end{array}$} & Under weight & 52 & 9.2 \\
\hline & Normal weight & 378 & 67.1 \\
\hline & Over weight/pre-obesity & 109 & 19.4 \\
\hline & Obesity level I & 22 & 3.9 \\
\hline & Obesity level III & 2 & 04 \\
\hline
\end{tabular}

Note 1: For classification of body mass index (BMI), there was 1 missing data.

Source: Research data, 2019.

For quantitative demographic variables, the descriptive analysis was extended to assess measures of central tendency and variability (table 3) and the histograms of the distributions (Graph 3).

Table 3 - Descriptive analysis of quantitative demographic variables - Measures of central tendency and variability

\begin{tabular}{l|ll|ll}
\hline Variable & Average & $\begin{array}{l}\text { Standard } \\
\text { deviation }\end{array}$ & Minimum & Maximum \\
\hline Height (in meters) & 1.70 & 0.09 & 1.45 & 1.92
\end{tabular}




\begin{tabular}{lllll} 
Weight (in Kilos) & 66.16 & 14.07 & 41.00 & 176.00 \\
BMI & 22.90 & 3.92 & 16.49 & 58.81 \\
\hline
\end{tabular}

Source: Research data, 2019.

For weight and BMI, two discrepant observations were obtained. Both refer to individuals with incomplete higher education and aged between 18 and 24 years old. The first is a woman with total family remuneration between 8 and 18 minimum wages, height of $1.60 \mathrm{~m}$, weight of $105 \mathrm{~kg}$ and BMI of 41.02 . For the second discrepant data, the characteristics are: male gender, total family remuneration above 18 minimum wages, $1.73 \mathrm{~m}, 176 \mathrm{~kg}$ and BMI of 58.81 .

Graph 1 - Descriptive analysis of quantitative demographic variables - Histogram

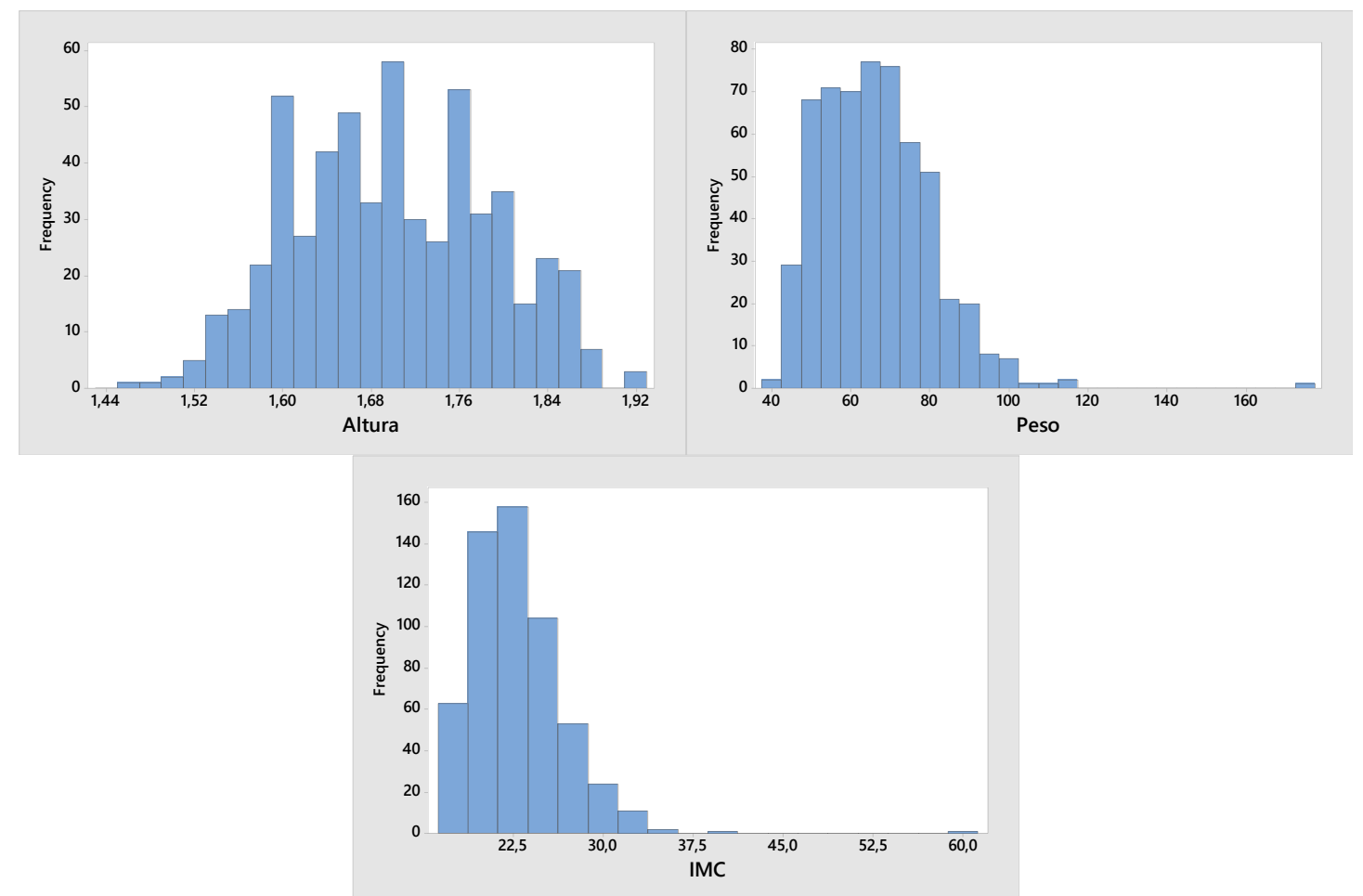

Source: Research data, 2019.

As for the histograms of the distributions, it was found that the height has a higher incidence between $1.60 \mathrm{~m}$ and $1.80 \mathrm{~m}$. Weight, in turn, has a predominance of values to the left of the graph in the range of approximately 50 to $80 \mathrm{~kg}$. Finally, BMI has an asymmetric distribution on the right with a predominance of observations close to 22.5 (normal weight), close to the data collected by the Food and Nutritional Surveillance System - Sisvan (2018), indicating an increasing weight gain and a percentage close to $25.4 \%$ of young people overweight.

\section{Analysis of the reliability of the instrument used in data collection}

In order to carry out the reliability analysis, the questions (indicators) present in the questionnaire were coded according to table 1. It is important to note that all respondents were instructed to answer the questionnaire based on their food consumption. 
Table 1 - Codification of the indicators present in the data collection instrument by dimension

\begin{tabular}{|c|c|}
\hline \multicolumn{2}{|c|}{ Product knowledge } \\
\hline PK1 & $\begin{array}{l}\text { When purchasing a product, I do not normally consider the potential damage it may cause } \\
\text { during consumption. }\end{array}$ \\
\hline PK2 & When buying a product, I am not sure if it will be harmful to me. \\
\hline PK3 & When buying a product, I don't always compare it with similar ones. \\
\hline PK4 & When buying a product, I don't always know similar products from other brands. \\
\hline PK5 & I don't have specific evaluation criteria for purchasing products. \\
\hline \multicolumn{2}{|c|}{ Product promotion } \\
\hline PP1 & I usually buy the products advertised in advertisements. \\
\hline PP2 & I usually buy the products recommended by the advertisements that are currently running. \\
\hline PP3 & $\begin{array}{l}\text { I usually make purchasing decisions according to the information made available by the } \\
\text { advertising of the products. }\end{array}$ \\
\hline PP4 & $\begin{array}{l}\text { I usually make purchasing decisions between similar products according to the characteristics } \\
\text { of each one presented by the advertisement. }\end{array}$ \\
\hline PP5 & I usually buy the products recommended by the communication actions of the markets. \\
\hline PP6 & I would buy a product without hesitation if its spokesman is a celebrity familiar to me. \\
\hline \multicolumn{2}{|c|}{ Social pressure } \\
\hline SP1 & I usually buy products to please others. \\
\hline SP2 & I usually buy products to meet other people's desires. \\
\hline SP3 & I usually buy products that do not cause disagreement with other people. \\
\hline SP4 & When buying a product, I usually look at other people around me. \\
\hline \multicolumn{2}{|c|}{ Refund policy } \\
\hline RF1 & I would buy a product even if it does not offer a money-back guarantee. \\
\hline RF2 & I would buy a product without feeling insecure if it offered a money-back guarantee. \\
\hline RF3 & $\begin{array}{l}\text { When buying a product, if there is a money-back guarantee, I make the purchase decision } \\
\text { without hesitation. }\end{array}$ \\
\hline \multicolumn{2}{|c|}{ Marketing and emotional pressure } \\
\hline MEP1 & I always change my decisions when I'm under the influence of the seller. \\
\hline MEP2 & Affectionate service will always make me buy more products. \\
\hline MEP3 & I often feel ashamed for refusing the seller's recommendation. \\
\hline MEP4 & My buying decisions are often influenced by my emotions. \\
\hline \multicolumn{2}{|c|}{ Distinguishability } \\
\hline DA1 & When buying a product, I usually do not know how to identify false information. \\
\hline DA2 & consumer. \\
\hline \multicolumn{2}{|c|}{ Purchase ability } \\
\hline PA1 & I usually buy a product similar to what I want for a lower price. \\
\hline PA2 & $\begin{array}{l}\text { When buying a product, I often have no alternative but to give up my first option and end up } \\
\text { choosing another simpler option. }\end{array}$ \\
\hline PA3 & When I buy a product, I often find that there are few options within my purchasing capacity. \\
\hline PA4 & I often don't get what I want and I have to buy a similar replacement product. \\
\hline \multicolumn{2}{|c|}{ Nutricional interest } \\
\hline IN1 & Today, I can say that I am interested in checking the nutritional information of the packages. \\
\hline IN2 & I believe that the nutritional tables on the packages provide a lot of useful information. \\
\hline IN3 & I regularly look at the nutrition information on the boxes. \\
\hline IN4 & I regularly use the nutritional information provided on the packaging. \\
\hline
\end{tabular}

Source: Shi et al. (2017) and Balasubramanian \& Cole (2002).

The reliability assessment was performed using the Cronbach's alpha and Cronbach's alpha coefficient (if deleted item), the results of which are presented in table 4 . For your analysis, the acceptability limit proposed by Hair et al. (2005), that is, 0.600 . 
Table 4 - Analysis of the reliability of the instrument used in data collection - Cronbach's alpha and Cronbach's alpha (if deleted item)

\begin{tabular}{l|l|l}
\hline Variable & Cronbach's Alpha & $\begin{array}{l}\text { Cronbach's Alpha (If deleted } \\
\text { item) }\end{array}$ \\
\hline Product knowledge & 0.664 & PK1: 0.665 \\
Product promotion & 0.834 & PP6: 0.863 \\
Social pressure & 0.809 & SP4: 0.833 \\
Refund policy & 0.407 & RF1: 0.510 \\
Marketing and emotional pressure & 0.704 & -- \\
Distinguishability & 0.663 & -- \\
Purchase ability & 0.744 & PA1: 0.766 \\
Nutricional Interest & 0.871 & IN2: 0.932 \\
\hline
\end{tabular}

Note 1: Cronbach's alpha value considers the inclusion of all indicators forming the dimension under analysis. Note 2: Cronbach's alpha column (if deleted) presented the indicator and the impact of its removal on the value of Cronbach's alpha coefficient of the dimension in which it is part. For example, the withdrawal of PK1 implied an increase in Cronbach's alpha coefficient of product knowledge, which went from 0.664 to 0.665.

Note 3: The withdrawal of any marketing and emotional pressure indicator implied an increase in Conbrach's alpha coefficient for this dimension.

Note 4: Cronbach's alpha coefficient (if deleted item) was not calculated for dimensions composed of only 2 indicators, as this is the minimum number of items for forming a dimension (Mesquita, 2010).

Source: Research data, 2019.

It was found that, of the 8 variables evaluated, 7 had Cronbach's alpha coefficients greater than 0.600. This result indicated the reliability of the scales and the consistency between the different indicators of each dimension. An exception was noted in refund policy, whose considerations will be made below. This result can be understood by the context in which the research was carried out, the food consumption market, in which return policies are not considered as relevant marketing tactics (Abicht et al., 2017).

The evaluation of Cronbach's alpha coefficients (if deleted) indicated that only the removal of two indicators (RF1 and INC2) caused a consistent increase in Cronbach's alpha coefficient of their respective dimensions, which increased, in this order, from 0.407 to 0.510 and from 0.871 to 0.932 . Therefore, we opted for the exclusion of the mentioned indicators. With this adjustment, refund policy obtained Cronbach's alpha coefficient of 0.510 (below the limit of 0.600 ), which motivated its elimination. Therefore, the analyses presented below do not consider the refund policy dimension.

\section{Descriptive analysis of nutritional interest and vulnerability dimensions}

Table 5 and graph 2 brought the results related to the descriptive analysis of nutritional interest and the dimensions of vulnerability.

Table 5 - Descriptive analysis of nutritional interest and vulnerability dimensions - Measures of central tendency and variability

\begin{tabular}{l|l|l|l|l}
\hline Variable & Average & $\begin{array}{l}\text { Standard } \\
\text { Deviation }\end{array}$ & Minimum & Maximum \\
\hline Nutricional Interest & 5.10 & 3.31 & 0.00 & 10.00 \\
Product knowledge & 4.21 & 1.96 & 0.00 & 10.00 \\
Product promotion & 4.00 & 2.03 & 0.00 & 10.00 \\
Social pressure & 2.36 & 2.15 & 0.00 & 10.00 \\
Marketing and emotional pressure & 5.00 & 2.15 & 0.00 & 10.00 \\
Distinguishability & 4.60 & 2.46 & 0.00 & 10.00 \\
Purchase ability & 5.54 & 2.03 & 0.00 & 10.00 \\
Vulnerability (global) & 4.29 & 1.36 & 0.48 & 10.00 \\
\hline
\end{tabular}


Source: Research data, 2019.

The highest average was observed in purchase ability $(M=5.54)$, therefore, this was the item of greatest agreement among those surveyed, it is a dimension linked to the consumer's ability to carry out evaluations of the alternatives that present the best cost-benefit relationships for them (Chi et al., 2017). Nutritional interest, in turn, obtained the highest standard deviation (SD = 3.31) and, consequently, the highest occurrence of distant responses in relation to the mean (which are: 0 and 10). Graph 2 reiterated these conclusions, given that: in purchase ability the highest frequencies were associated with responses close to 5.54; the highest frequencies of 0 and 10 were observed in nutritional interest, while the values between these two extremes maintained frequencies close to each other.

Graph 2 - Descriptive analysis of nutritional interest and vulnerability dimensions - Histogram

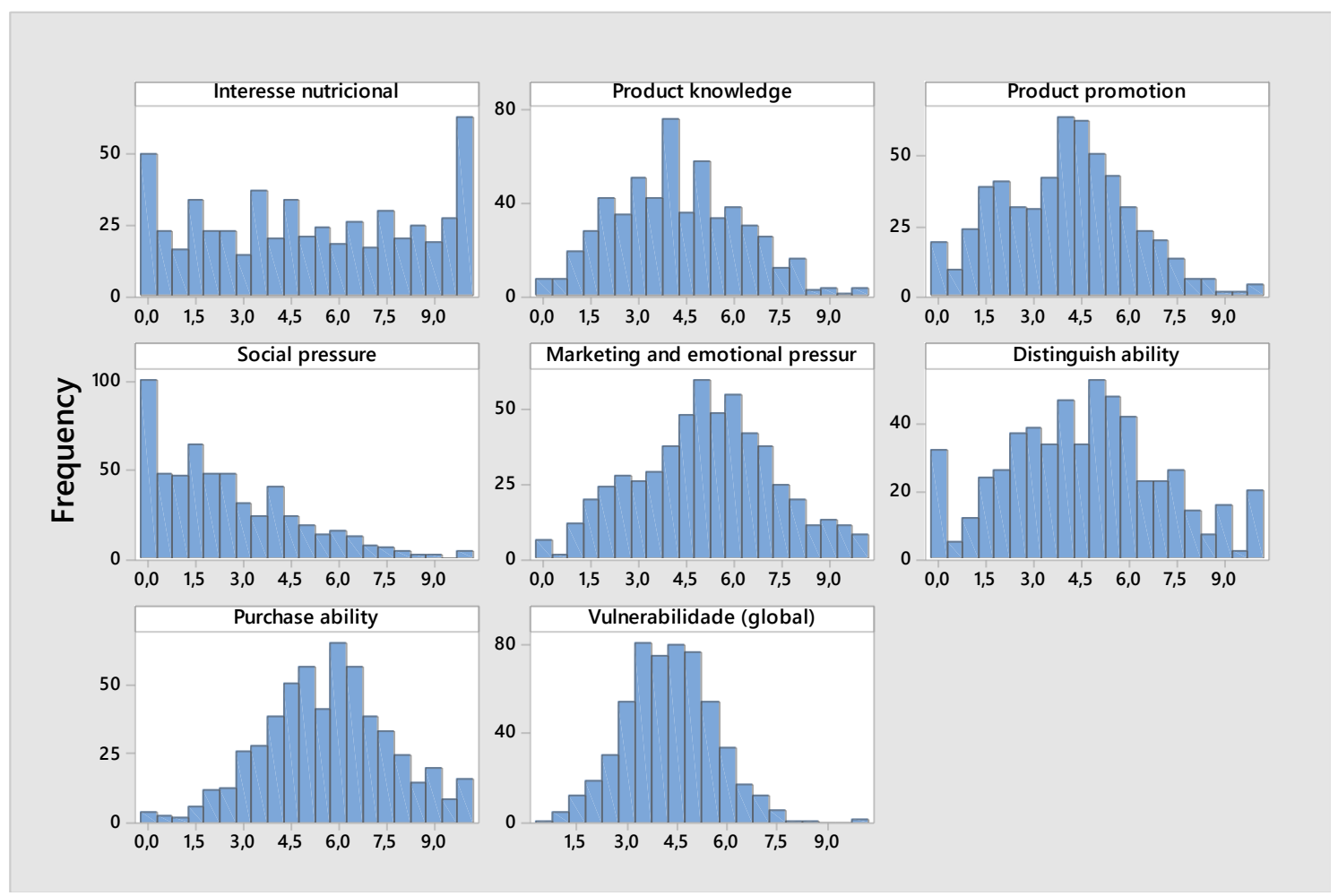

Source: Research data, 2019.

\section{Regression analysis}

The first step in performing the regression analysis was to select the variables that entered the model. For this purpose, the relationship between the dependent and independent variables was evaluated using 3 strategies: Spearman correlation (table 6), dispersion graph (graph 3) and box-plot (graph 4). 
Table 6 - Analysis of the relationship between nutritional interest, vulnerability dimensions and BMI - Spearman correlation

\begin{tabular}{l|l|l|l|l|l|l|l|l}
\hline & 1 & 2 & 3 & 4 & 5 & 6 & 7 & 8 \\
\hline $\begin{array}{l}\text { I) Nutritional interest } \\
\text { 2) Product knowledge }\end{array}$ & -- & $-0.320^{* *}$ & - & & & & & \\
3) Product promotion & -0.055 & $0.286^{* *}$ & -- & & & & & \\
4) Social pressure & 0006 & $0.191^{* *}$ & $0.360^{* *}$ & -- & & & & \\
5) Marketing and emotional & -0.040 & $0.236^{* *}$ & $0.408^{* *}$ & $0.339^{* *}$ & -- & & & \\
pressure & & & & & & & & \\
6) Distinguishability & $-0.126^{* *}$ & $0.399^{* *}$ & $0.226^{* *}$ & $0.182^{* *}$ & $0.328^{* *}$ & -- & & \\
7) Purchase ability & 0.052 & $0.180^{* *}$ & $0.162^{* *}$ & $0.181^{* *}$ & $0.258^{* *}$ & $0.261^{* *}$ & - & \\
8) Vulnerability (global) & $-0.130^{* *}$ & $0.586^{* *}$ & $0.628^{* *}$ & $0.579^{* *}$ & $0.684^{* *}$ & $0.656^{* *}$ & $0.527^{* *}$ & -- \\
9) BMI & 0.038 & 0.050 & 0.059 & -0.003 & 0.053 & 0.029 & 0.028 & 0.049 \\
\hline
\end{tabular}

Note: ** indicates that the correlation is significant at the 0.01 level ( 2 ends).

Source: Research data, 2019.

As for the correlation analysis, there was a significant coefficient in the relationship between nutritional interest and product knowledge $(r=-0.320, \mathrm{p}<0.01)$. This result indicated that, while one variable increases, the other tends to decrease, that is, the more one knows about a product, the less the consumer is dependent on market attributes (Afzal et al., 2009). Global vulnerability $(r=-0.130, p<0.01$ ) and distinguishability $(\mathrm{r}=-0.126, \mathrm{p}<0.01)$ also showed significant correlations with the response variable , however, without this indicating practical significance (Gujarati; Porter, 2011).

Graph 3 - Analysis of the relationship between nutritional interest, vulnerability dimensions and BMI Dispersion graph

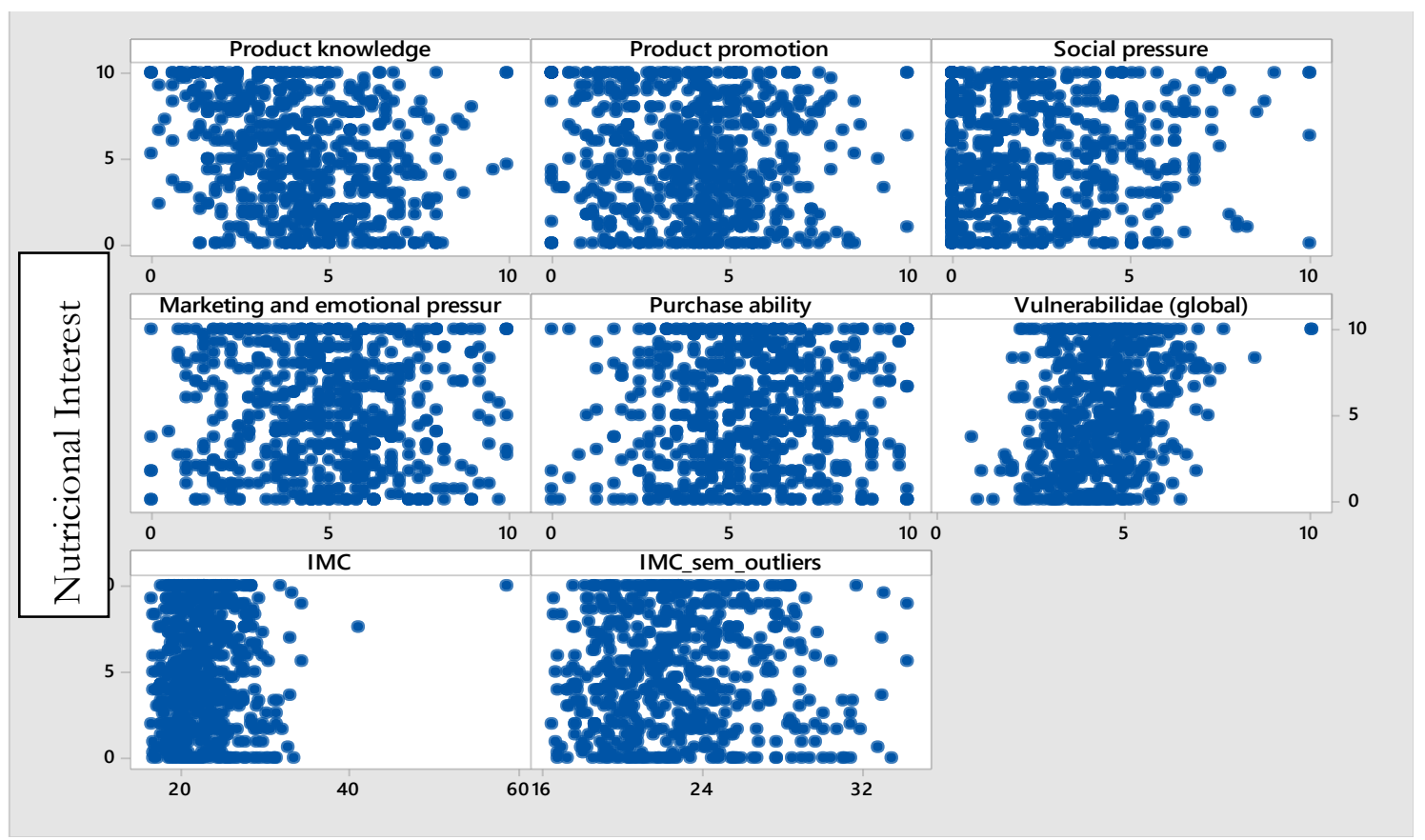

Source: Research data, 2019.

The association between nutritional interest and product knowledge was reiterated in Graph 3, since it was possible to visualize a decreasing trend in the values of the first variable from the increase in the scores of the second. In the other cases, the apparently random arrangement of the points indicated that that nutritional interest is not linked to any of the variables considered (not even with the removal of the 
BMI outliers it was possible to identify any pattern). Graph 4 evaluated how nutritional interest is linked qualitative demographic data.

Graph 4 - Analysis of the relationship between nutritional interest and qualitative demographic variables - Box plot
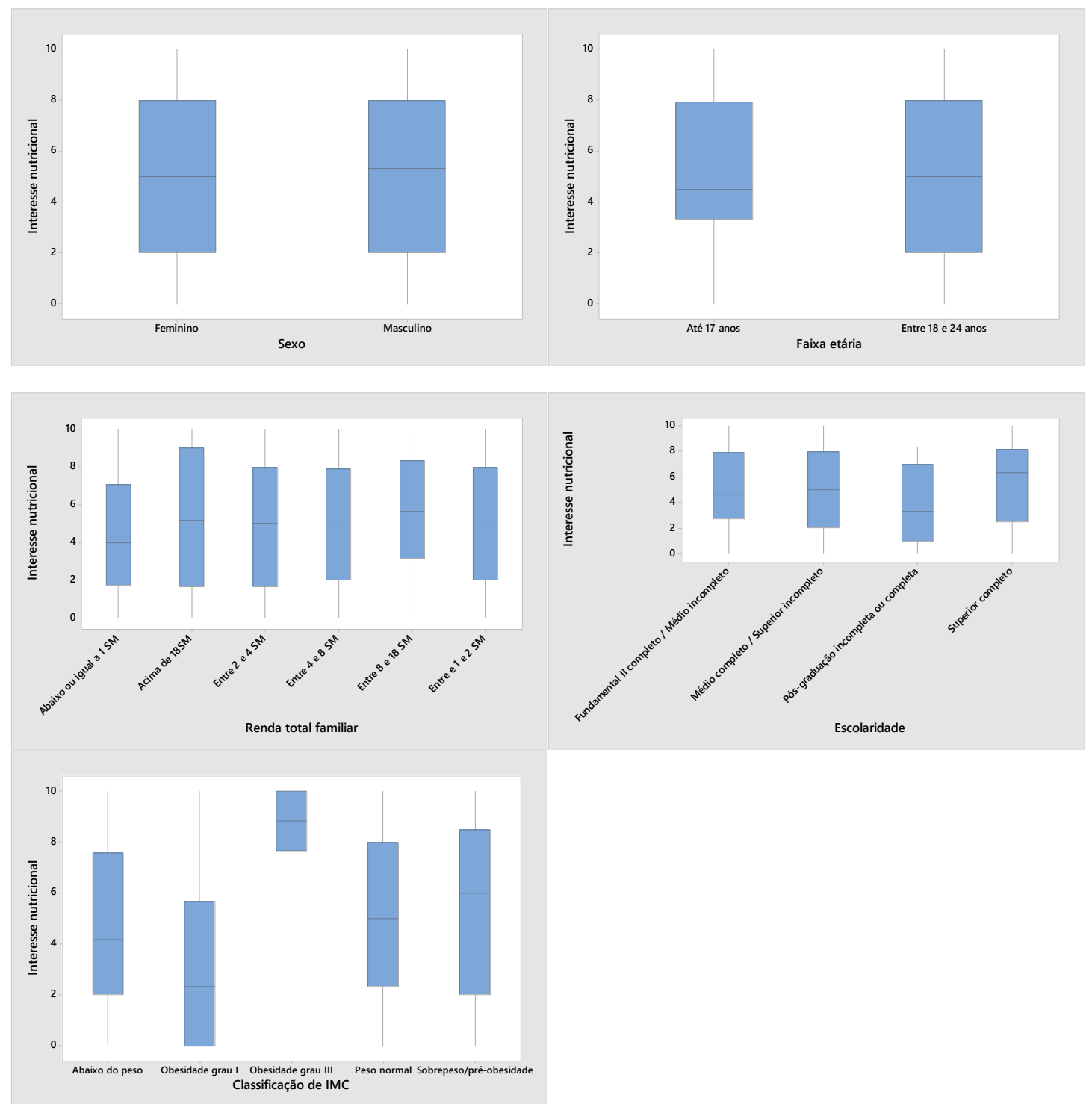

Source: Research data, 2019.

It was found that the response variable barely changes in relation to the different categories of sex, age group, total family income and education, and; it undergoes modifications due to the different BMI classification groups, a result that enabled the entry of this predictor in the analysis. Therefore, the variables that entered the model were product knowledge and BMI classification.

The first linear regression analysis performed considered all 564 respondents and showed a violation in the assumptions of homoscedasticity and normality of the residues that cannot be circumvented despite the different approaches used. In the search for a viable alternative to quantify the relationship between the response variable and the independent ones, it was verified how the relationship between nutritional interest and product knowledge occurred in the different classification groups and BMI (graph 5). 
Graph 5 - Analysis of the relationship between nutritional interest and product knowledge by BMI classification group - Dispersion graph

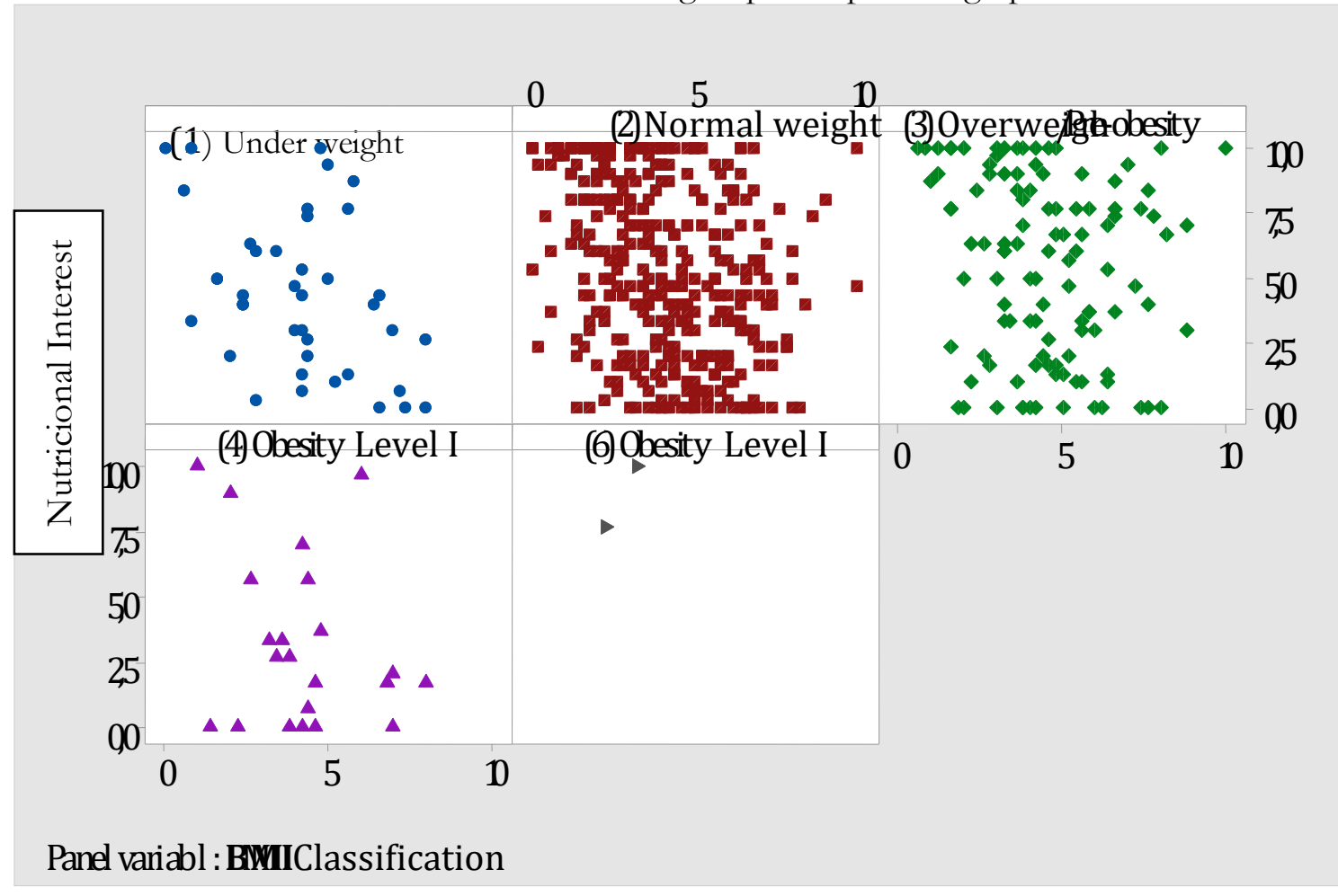

Source: Research data, 2019

It was possible to perceive the existence of a relationship between nutritional interest and product knowledge in the underweight and level I obesity groups. With this conclusion, it was decided to restart the regression analysis from the evaluation of the relationship between the response variable and each of the predictors in the different BMI classification groups, except level III obesity, which presented only 2 observations.

Thus, it was concluded that nutritional interest is not related to any of the independent variables in the BMI classification groups normal weight and overweight/pre-obesity; it relates to product knowledge and purchase ability in the underweight group; it relates to BMI in the grade I obesity group.

Therefore, two new regression analyzes were performed, the results of which are shown in Table 7. With the intention of safeguarding the assumptions of this multivariate data analysis technique, it was necessary to perform a transformation in the response variable (which became $(\sqrt{\mathrm{INl}})$ ) in the underweight group.

Table 7 - Analysis of the relationship between nutritional interest and independent variables by BMI classification group - Regression analysis

\begin{tabular}{|c|c|c|c|c|c|}
\hline Variable / intercept & Estimate & $\begin{array}{l}\text { Standard } \\
\text { error }\end{array}$ & $\mathrm{t}$ & $\begin{array}{l}\mathrm{P} \\
\text { Value }\end{array}$ & IVF \\
\hline \multicolumn{6}{|l|}{ UNDER WEIGHT } \\
\hline Intercept & 2.069 & 0.308 & 6.720 & $\begin{array}{l}< \\
0.001\end{array}$ & -- \\
\hline Product knowledge (pk) & -0.217 & 0.048 & -4.460 & $\begin{array}{l}< \\
0.001\end{array}$ & 1.07 \\
\hline
\end{tabular}




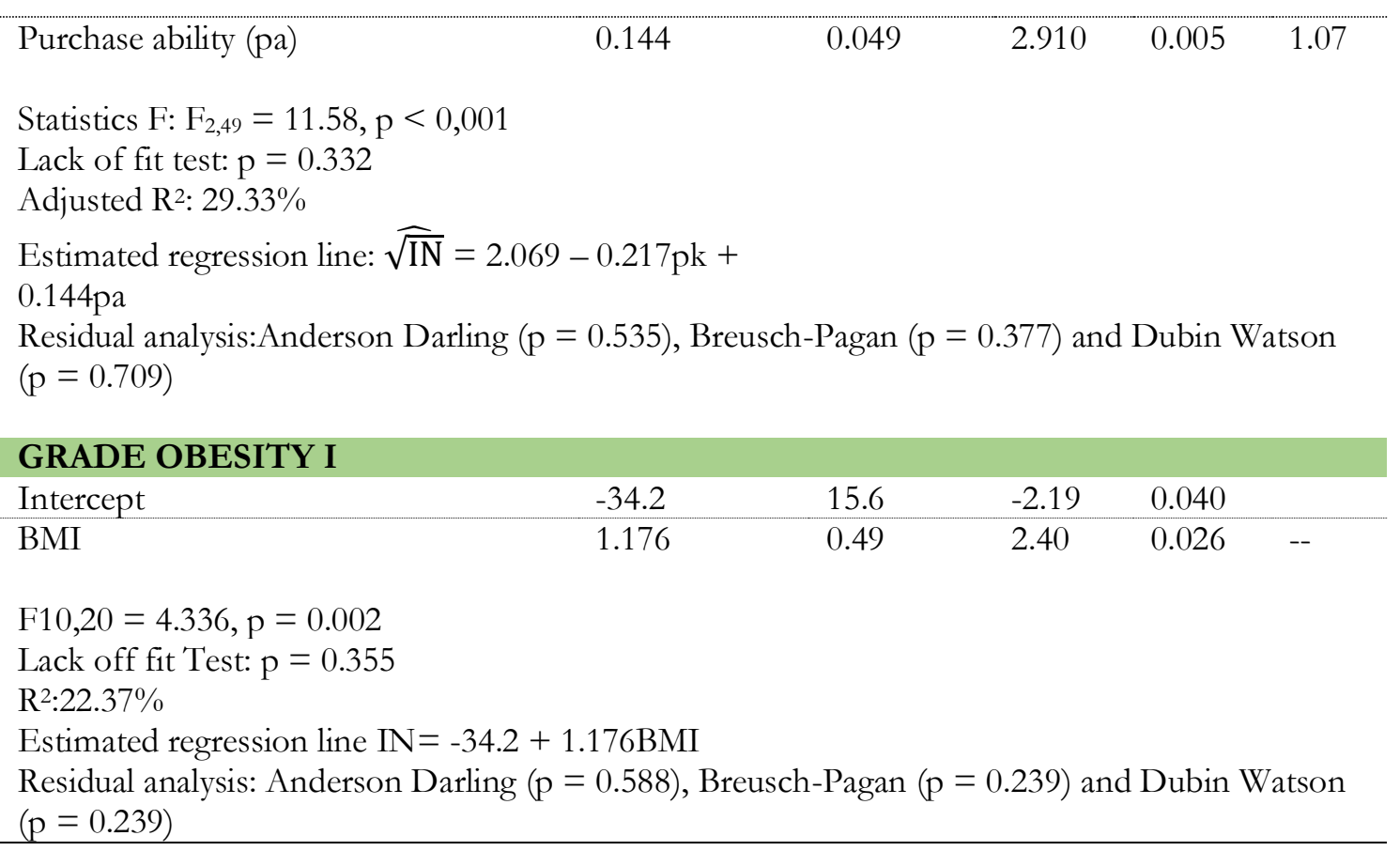

For the underweight group, the results indicated that: for the same level of purchase ability, the increase of one unit in product knowledge implies a decrease, on average, of 0.217 unit in the square root of nutritional interest; for the same level of product knowledge, the increase of one unit in purchase ability implies an increase, on average, of 0.144 unit in the square root of nutritional interest; $29.33 \%$ of the variance of $\sqrt{\mathrm{IN}}$ around its mean was explained by PK and PA; the estimated regression line was: $\sqrt{\mathrm{IN}}=$ $2.069-0.217 \mathrm{pk}+0.144 \mathrm{pa}$.

For the grade I obesity group, the results indicated that: an increase of one unit in BMI implies an increase, on average, of 1.176 in nutritional interest; $22.37 \%$ of the $\hat{Y}$ variance around its mean was explained by BMI; the estimated regression line was: $\mathrm{IN}=-34.2+1.176 \mathrm{BMI}$.

In the first regression, the VIF value indicated that there was no multicollinearity between the independent variables considered in the model.

The adjusted R2 and R2 values were close to what is expected from studies carried out in the area of Applied Social Sciences. On this subject Marques and Borges (2015) explain that, in Applied Social Sciences, the coefficient of determination is around 30.0\% (Marques, Borges and Reis, 2015).

The analysis of residues from both models indicated compliance with the assumptions of normality, homoscedasticity and the absence of self-correlation of the residues, since all p-values associated with Anderson Darling, BreuschPagan and Durbin Watson tests were higher than the significance level employed (5\%).

From these results, it was possible to identify more evidence of significance between knowledge of the product and nutritional interest. This reinforces the importance of information for the satisfactory evaluation of the consumer (Mascarenhas et al., 2008), making the consumer more vulnerable in case of information asymmetry (Cooper-Martin, 1997), which reinforces the duty of care provided by the legislation, especially with regard to correct and complete information (Novais, 2006). Thus, even though the consumer cannot retain productive knowledge, he has some elements to make his purchase decision, especially the information available by companies through different means, such as advertising and labels. 
Since there is a direct correlation between such variables, the consumer will probably process the information for decision making a few times, automatically performing it on other purchase occasions (Darren, 2018) which reinforces the need for correct information.

\section{Final considerations}

Returning to the objective of this work, it was possible to measure the vulnerability of young adults through the scale proposed by Chi et al. (2017), consisting of seven dimensions, namely: product knowledge, promotion / advertising, social pressure, reimbursement policies, marketing and emotional pressure, ability to distinguish and purchase capacity, relating these dimensions to the nutritional scale of Cole (2002). The scales proved to be appropriate to support revealing conclusions about the food vulnerability of consumers in Brazil. Thus, a series of notes need to be emphasized. First, as presented above, the initiative to reinforce nutritional information needs to be on the agenda of concerns of marketing managers and product and food product packaging developers so that consumers can be aware of the type of product they are consuming. Second, it is necessary to carry out educational campaigns that emphasize the consumer's need to seek nutritional information on products. At this point, consumer protection agencies need to take a leading role. Thirdly, public managers and, above all, legislators need to be aware of the creation of laws that can emphasize these issues and punish those companies that do not comply with these guidelines.

The research sheds light on the theme of vulnerability, something very important that, in addition to having an importance in the field of discussions involving marketing and society, also adheres to public policies. So, vulnerability, in the context of food consumption and with the age range used, changes little in relation to the variables sex, age group, total family income and education, however, one cannot fail to notice the predominance of responses between the income brackets of two and eight minimum wages and education of complete high school or incomplete higher education, which gives a certain homogeneity of profile. An interesting fact is that there is a relationship between nutritional interest and product knowledge in underweight and grade I obesity groups. Thus, one can relate the possible nutritional interest to weight maintenance and the greatest nutritional interest when the individual realizes that he/she is beyond normal weight and needs to take action to minimize the health risk factor. What reinforces this argument lies in the aforementioned influence that with each increase of one unit in BMI implies an increase, on average, of 1,176 units in nutritional interest. The underweight group still demonstrated greater purchasing ability, which demonstrates greater attention to what is being consumed over several attributes.

Thus, this research reinforces the power of persuasion over consumers through the information provided by suppliers and also highlights the importance of understanding the mandatory information provided by law or not, so that the consumer can make the best food purchase decisions in order to maintain their health. It is suggested for future research to carry out qualitative studies regarding internal influences on food vulnerability, quantitative studies with formation of clusters and the relationship with vulnerability in the food market, among other possibilities. Given the emergence of the theme for several areas, not only for the areas of health or law, management, especially marketing, needs to occupy its space of responsibility in terms of analyzing the impact of its practices on the market and their reflection on the health of society.

\section{References}

Abicht, A. M., Cunha, A. C., Ceolin, A. C., \& Bernardes, M. M. S. (2017). Cocriação de valor dos clientes em Uma trading de alimentos:Marketing para o setor alimentício, Ed. 1, Belo Horizonte, Poison.

ACR - Association for Consumer Research. Transformative Consumer Research. (2019). Disponível em <http://www.acrwebsite.org/web/tcr/transformative-consumer-research.aspx>. Acesso em: 30 dez. 2019. 
Afzal, W., Roland, D., \& Al-Squri, M. N. (2009). Information asymmetry and product valuation: an exploratory study. Journal of Information Science, 35, 192-203.

Almeida, G. T., Batinga, G. L., Ássimos, B. M., \& Pinto, M. R. (2017). Uma perspectiva transformadora entre consumidores idosos de baixa renda no contexto de consumo de crédito e violência financeira. XLI EnANPAD. São Paulo: Anais, 1-16.

Alves, F. G., \& Varella, M. H. (2016). Regulamentação da rotulagem dos alimentos vegetarianos sob a perspectiva do código de defesa do consumidor. Cadernos de Pós-Graduação em Direito/UFRGS, 11(3).

Ássimos, B. M., Pinto, M. R., Batinga, G. L., \& Almeida, G. T. (2017). Justiça social e transformative consumer research: a proposição de uma reflexão teórica. Consumer Bebavior Review, 1 (Special Edition) 16-31.

Baker, S. M., Gentry, J. W., \&Rittenburg, T. L. (2005). Building understanding of the domain of consumer vulnerability. Journal of Macromarketing, 25(2), 128-139.

Balasubramanian, S. K., \& Cole, C. (2002). Consumers Search and Use of Nutrition Information: The Challenge and Promise of the Nutrition Labeling and Education Act. JM, 66, 112-127.

Benjamin, A. H. V., Marques, C. L., \& Bessa, L. R. (2014). Manual de direito do consumidor. $6^{a}$ Ed. São Paulo: Revista dos Tribunais.

BRASIL. (1969). Decreto-Lei no 986, de 21 de outubro de 1969. Institui normas básicas sobre alimentos.

. Lei Federal $n^{\circ} 10.674$, de 16 de maio de 2003. Obriga a que os produtos alimentícios comercializados informem sobre a presença de glúten, como medida preventiva e de controle da doença celíaca.

Lei Federal no 8.078, de 11 de setembro de 1990. Dispõe sobre a proteção do consumidor e dá outras providências.

. Lei Federal no 9.782, de 26 de janeiro de 1999. Define o Sistema Nacional de Vigilância Sanitária, cria a Agência Nacional de Vigilância Sanitária, e dá outras providências.

. Resolução de Diretoria Colegiada da Agência Nacional de Vigilância Sanitária no 360, de 23 de dezembro de 2003. Disponível em: <http://portal.anvisa.gov.br/documents/33880/2568070/res0360_23_12_2003.pdf/5d4fc713-9c66-4512b3c1-afee57e7d9bc>. Acesso em 02 jun. 2020.

Resolução de Diretoria Colegiada da Agência Nacional de Vigilância Sanitária no 26, de 02 de julho de 2015. Dispõe sobre os requisitos para rotulagem obrigatória dos principais alimentos que causam alergias alimentares. Disponível em: < http://www.abic.com.br/publique/media/rdc26.pdf>. Acesso em: 02 jan. 2020.

BRASIL. (2014). Conselho Nacional de Segurança Alimentar e Nutricional - CONSEA. Seminário Pesquisa em SAN: Relatório final. Brasília: Presidência da República, 2014.

Bridger, D. (2018). Neuromarketing: como a neurociência aliada ao design pode aumentar o engajamento e a influência sobre os consumidores. $1^{a}$ ed. São Paulo: Autêntica Business.

Canella, D. S. et al. (2018). Consumo de hortaliças e sua relação com os alimentos ultraprocessados no Brasil. Revista de Saúde Pública, 52(50).

Charrad, M., Ghazzali, N., Boiteau, V., \& Niknafs, A. (2014). NbClust: An R Package for Determining the Relevant Number of Clusters in a Data Set. Journal of Statistical Software, 61(6), 1-36.

Chazal, J.-P. (2000). Vulnérabilité et droit de la consommation: colloque sur la vulnérabilité et le droit, organisé par l'Université P. Mendès-France, Grenoble II.

Commuri, S., \& Ekici, A. (2008). An enlargement of the notion of consumer vulnerability. Journal of Macromarketing, 28(2), 183-186.

Dworkin, R. (2010). Levando os direitos a sério. $3^{\mathrm{a}}$ ed. São Paulo: Martins Fontes.

Fricke, R. M., Battisti, I. D. E., \& Corrente, A. E. E. (2009). Métodos Estatísticos e a Administração. Ijuí: Ed. Unijuí.

Garrett, D. E., \& Toumanoff, P. G. (2010). Are consumers disadvantaged or vulnerable? An examination of consumer complaints to the better business bureau. Journal of Consumer Affairs, 44(1), 3-23.

Grinover, A. P. et al. (2011). Código brasileiro de defesa do consumidor: comentado pelos autores do anteprojeto. $10^{\mathrm{a}} \mathrm{ed}$. Rio de Janeiro: Forense. 
Gujarati, D. N., \& Porter, D. C. (2011). Econometria Básica, 5a ed. Bookman: Porto Alegre, 2011.

Hair Jr., J. F., Anderson, R. E., Tatham, R. L., \& Black W. C. (2005). Análise multivariada de dados, $5^{\mathrm{a}}$ ed. Porto Alegre: Bookman.

Instituto Brasileiro De Geografia E Estatística - IBGE. Segurança alimentar 2004/2009. Rio de Janeiro, 186 p. Disponível em:

<http:www.ibge.gov.br/home/estatística/população/segurança_alimentar_2004_2009/default.shtm> Acesso em jan. 2020, 2010.

Jae, H., \& Viswanathan, M. (2012). Effects of pictorial product-warnings on low-literate consumers. Journalof Business Research, 65(12), 1674-1682.

Marques, C. L. (2014). Contratos no Código de Defesa do Consumidor: o novo regime das relações contratuais. $7^{\text {a }}$ ed. São Paulo: Revista dos Tribunais.

Mesquita, J. M. C. (2010). Estatística multivariada aplicada a Administração. Curitiba: Editora CRV.

Mingoti, S. A. (2005). Análise de dados através de métodos de estatística multivariada: uma abordagem aplicada. Belo Horizonte: Editora UFMG.

Moraes, P. V. P. (1999). Código de defesa do consumidor: no contrato, na publicidade, nas demais práticas comerciais. Porto Alegre: Síntese.

Novais, J. R. (2006). Direitos fundamentais: trunfos contra a maioria. Coimbra: Coimbra Editora.

Nunes, L. A. R. (2013). A elevação da demanda pelo crescimento da população urbana, sem tempo ou espaço para produção própria, e a consequente produção em série. Curso de direito do consumidor. $8^{a}$ ed. São Paulo: Saraiva.

Oecd Health Policy Studies. (2019). Health in the 21st Century. Disponível em: <https://www.oecdilibrary.org/social-issues-migration-health/health-in-the-21st-century_e3b23f8e-en> Acesso em out. 2019.

Pasqualotto, A., \& Soares, F. R. (2017). Consumidor hipervulnerável: análise crítica, substrato axiológico, contornos e abrangência. Revista de Direito do Consumidor, 113, 81-109.

Paula, G. A. (2013). Modelos de regressão com apoio computacional.

Ringold, D. J. (2005). Vulnerability in the marketplace: Concepts, caveats, and possible solutions. Journal of Macromarketing, 25(2), 202-214.

Shi, H. Y., Jing, F. J., Yang, Y., \& Nguyen, B. (2017). The concept of consumer vulnerability: Scale development and validation. International Journal of Consumer Studies. 41, 769-777.

Silva F. M. et al. (2018). Consumption of ultra-processed food and obesity: cross sectional results from the Brazilian Longitudinal Study of Adult Health (ELSA-Brasil) cohort (2008-2010). Public Health Nutrition, 21, 12, 2271-2279.

Silva, R. O., Barros, D. F., Gouveia, T. M. O. A., \& Merabet, D. O. B. (2016). Vulnerabilidade do Consumidor: Uma Discussão Necessária do Ponto de Vista Acadêmico e Social. XVII Congresso Nacional de Administração e Contabilidade - AdCont.

SISVAN - Sistema de Vigilância Alimentar e Nutricional. (2018). Módulo de relatórios públicos. Disponível em: $<$ http://sisaps.saude.gov.br/sisvan/relatoriopublico/index> Acesso em jan. 2020.

Solomon, M. R. (2010). Comportamento do Consumidor: Comprando, Possuindo e Sendo. $9^{a}$ edição. Porto Alegre: Bookman.

Superior Tribunal de Justiça. Recurso Especial 1.558.086-SP. Segunda Turma. rel. Min. Humberto Martins. j. 10.03.2016. Disponível em: [www.stj.jus.br]. Disponível em: [http://criancaeconsumo.org.br/wpcontent/uploads/2014/02/Datafolha_alimentos_regulacao_ACT.pdf]. Acesso em: 18.01.2020. 